Theories \& Applications, the International Edition

Printed Version: (ISSN 2090-5262)

Online Version: (ISSN 2090-5270)

July 2013, Volume 3, No. 2 Pages (185 - 198)

\title{
The Preliminary Phase of Junior Athlete Selection for the Sport Human Genome Project in Some Track and Field Events (Phase II)
}

\author{
Samy Ibrahim Nasr*, Medhat Abdel Hamid Salem**, Saad Fathalla Elalem***
}

\begin{abstract}
There is strong evidence that genes and genetic factors influence physical performance. This was why we developed the Sport Human Genome Project (SHGP), aiming at selecting junior players in some track and field events. Phase I of the project has already been completed and the present study aimed at implementing Phase II. This was done through identifying the genetic patterns of the ACE (DD,II) gene and the ACTN3 (RR,XX), and determining the best human elements according to genetic tests. The research sample consisted of 20 junior athletes with ages in the range $13.80 \pm 0.410$, who were selected in Phase I of the project. Morphological, physical and physiological measurements were taken of the sample, with the aim of finding those with genetic patterns for the ACE and ACTN3 genes through analysis of the DNA of blood sample using the polymerase chain reaction (PCR) and comparing the differences between groups of genetic patterns. Results showed the distribution of the genetic patterns of the ACE gene (genetic pattern ID: 70\%; genetic pattern II: 10\% and genetic pattern DD: 20\%) and the genetic patterns of the ACTN3 gene (the genetic pattern RX: 60\%; the genetic pattern RR: 20\% and the genetic pattern $X X: 20 \%)$ in the research sample. Another result was that genetic patterns are closely related to the selection of juniors. Individuals with the genetic pattern ACE II demonstrated greater ability in endurance activities, while those with the genetic pattern ACTN3 RR showed greater ability in speed activities. The best human elements constituted $30 \%$ of the sample size, based on genetic tests. The study recommended starting Phase III of the SHGP project on some track and field events.
\end{abstract}

Keywords: juniors, genes, the ACE gene, the ACTN3 gene, the Sport Human Genome Project (SHGP), selection, selection of talented people, track and field events

\section{Introduction}

Selection is a topic that has recently been in focus. The process, aiming at selecting those athletes with special talents in their respective sports, is such a complicated one that it demands a lot of procedures involving the use of tools of measurement and diagnosis which are based on science. Talented players are then

\footnotetext{
* Professor, Track and Field Events Training Department, Faculty of Physical Education ,Abu Qir, Alexandria University, Egypt.

** Lecturer, Track and Field Events Training Department, Faculty of Physical Education,Abu Qir, Alexandria University, Egypt.

*** Lecturer, Track and Field Events Training Department, Faculty of Physical Education ,Abu Qir, Alexandria University, Egypt.
}

selected, in consecutive phases, from among junior players with special abilities predicting achievement of the highest sport levels.

The achievement of success in sport depends on selecting the best talents, developing effective training methods and strengthening the infrastructure through scientific research. (30)

Outstanding achievements made by East African athletes in the running events have been controversial worldwide. Several theories sought to explain the reasons for such achievements. Unequaled successes made by African athletes in short and long distances events were usually attributed, to genetic tendencies, social and cultural socialization or sound nutrition systems. (21) 
Studies previously made recommended the use of scientific methods in selecting talented athletes and predicting their status in the future through national projects developed for the selection of talented athletes to be consecutively phased and which are carried out over appropriate time spans. Many countries depend on such projects to select talented athletes through specific phases and objectives, Hadavi F and Tarbiat, A. Z. (2009) designed a Talent Identification and Development Model in Iranian Athletics which consisted of three phases (initial selection, general tests and special tests) with specific aims such as determining unsuitable children for athletic fields, determining the abilities of the youth for track and field and improving the special abilities required of athletes. (11)

J.Schiffer (2008), citing Dempster (2005), suggested the following three phases for the talent development process in track and field events:

- The basic phase, in the age span $8-12$ years old, concentrating on the fun of participation and the participation in recreational games providing the basics of track and field events and developing speed, strength and endurance;

- The training for training phase, in the age span 13 - 16 years old, concentrating on the gradual acquisition of the concept of training, rather than on playing, while attending to the general physical preparation;

- The training to win phase concentrating on performance, and achieving maximum improvement in physical abilities, skills and competition. (28)

In Qatar, the Aspire Academy for excellence in sport adopted an innovative programme to identify and develop the best sport youth talents in the Arab World and in he world. The programme consists of three phases, each with its own aims and tests as follows:

- The Bronze Phase: in this phase emphasis is laid on testing the largest number possible of school students to detect those talented. The selection process is annually implemented in Qatar nationwide, and involves testing a student's body shape (height, weight, body mass, 40m sprint speed, throwing a medical ball, vertical jump and a $20 \mathrm{~m}$ shuttle run).

- The Silver Phase: here, 5\% of the precedent phase are nominated through an evaluation process of wider range of tests and observations, including measurements of body shape, speed, strength, ability, agility and endurance.

- The Gold Phase: in this phase, about $25 \%$ of students in the precedent phases are selected and undergo further scientific testing including physiological, biomechanical and physiological aspects, and finally $30-40 \%$ of the talented students are nominated for the Aspire Academy scholarships. (25)

In Egypt, many national projects were carried out to select juniors, but were unsuccessful and did not achieve their aims according to Al-Said Al-Qardawi (2007) who found several shortcomings with the projects and their aims. These were attributed to lack of human resources, lack of a scientific approach, inadequate evaluation tools, the low digital level of juniors, and participation (in the projects) by juniors already registered with clubs.(2)

In spite of that, the talent identification process in the above - mentioned projects still count on a number of physical, morphological and physiological tests which are not sufficient to ensure that a junior has the appropriate genetic aptitude to reach higher levels, or to show that physical factors and latent abilities do not appear all of a sudden, but over different stages of the junior's life. This was why we developed the Sport Human Genome Project (SHGP) in some track and field events, to be implemented over four phases, as follows:

- Phase I: in this phase, preliminary selection of juniors is carried out through observation and anthropometric, morphological, physiological and medical measurements;

- Phase II: based on Phase I, an in-depth examination is made of the type of activity after practice, i.e., events characterized with speed and endurance. Genetic tests are introduced in this phase.

- Phase III: this is the stage of sports orientation towards the appropriate sport (speed - endurance), which is carried out based on results of Phase II;

- Phase IV: Here, national teams are selected. 
This project capitalizes on conclusions of modern studies on talent selection. Several studies were recently published on heredity, genetics and the role played by heredity in sports activity, and many countries are adopting theories on the subject. Studying the genetic characters and the genes are important in selection in sport as they are considered responsible for physical performance variables and the response to sports training.

Phase I of the project was implemented in 2008 and led to the identification of the best human elements and the distinguished persons, and a map was drawn of the best genetic models of the juniors. It is high time Phase II started (selecting according to genes), and this is the subject of this present study. (27)

Improving sports performance requires selected processes which are based on an integrated scientific approach covering all aspects (morphological, physical, physiological and genetic). In Phase I, we predicted the "horror day of sport" that would witness new records achieved beginning from the Beijing 2008 Olympics, which came true with unbelievable records especially in the $100 \mathrm{~m}$ and $200 \mathrm{~m}$ sprints. New records followed in the London Olympics of 2012.

Authors of this paper suggest that genetic selection is instrumental in identifying a champion. Selecting and identifying talents, especially after the astounding records already achieved, will be more difficult, and predicting a talent will not depend on luck and experience. More countries are now keen on carrying out a real process of selection and separating promising juniors from others based on genetic selection.

Heredity plays an essential role in detecting and finding sport talents and constitute $40 \%-50 \%$ of the talent. Genes develop and improve the physiological capacity of a sports person and influence anabolism, response to training, compatibility of the circulatory system, developing speed and muscular strength. (20)

The Human Genome Project, an outcome of modern technologies, was the starting point of the consideration given to heredity, (30) The project aimed at identifying genes containing he human DNA in order to use it in genetic therapy and develop new drugs and medicaments. The rapid progress achieved in the project laid the ground for our study on sport-related and performance-related genes, seeking to identify such genes and explore heir effect on sport. (19)

Scientists studied and identified the sportrelated genes, the most important of which was the angiotensin - converting enzyme (ACE) in its two forms: (II, DD), called the performance gene, and the gene ACTN3 in its two forms (RR, XX), called the athletes gene. (26)

The ACE gene is the most important gene and the most frequently studied one in the field of sport performance. The ACE is located on the long (q) arm of chromosome 17 at position $17 \mathrm{q} 23$ and consists of 25 exons, (1) ACE plays an important role in the maintenance of cardiovascular homeostasis through both constricting blood vessels by angiotensin (II), thus producing aldosteron, and reducing kinin to induce vasodilation. The multi-form human genome ACE is identified in two ways: by insertion (I-allele) and by deletion (D-allele) associated with the reduction of the ACE enzyme activity in blood and tissues. (1)

The ACE gene produces the ACE enzyme which converts inactive ACE I into active ACE II, responsible for regulating blood pressure and cardiovascular functions. The ACE gene has three forms: ACE II, ACE DD and ACE ID. (5)

Numerous studies proved that the ACE gene genotypes are closely related to sports performance. Elite endurance athletes demonstrate existence of the II genotype, responsible for the power of endurance in athletes. (1), (29), whereas the DD genotype is frequently demonstrated in speed and strength athletes. (26), (32)

Rightly called the gene of athletes, especially among top level and speed athletes, the ACTN3 gene is one of the most important genes in sports. Locus of ACTN3 is 11q13 - q14, on the long (q) arm of chromosome 11 on the bands 13 and 14. (26). ACTN3 was identified in three forms (RR, RX, XX) and found to be related to sport performance. It is the gene responsible for producing the Alpha-actinin-3 protein, which is found in type II of the fast muscle fibers, and which helps muscles contract most rapidly and forcefully. (12). The ACTN3 gene controls the 
protein forming the sacromeric area in the muscle fiber and is only found in the fast muscle fibers responsible for generating force in high speeds. The genetic variation of the ACTN3 gene has two forms: RR and XX. RR has been found by several studies to be related to force and speed in athletes, and presence or absence of acinin-3 may affect activities of sprinting and strength through fast muscle fibers, which can easily be noticed in maximum performances (1), (33), while the $X$ allele and genotype XX may not be decisive in performance of endurance. (9).

The genotypes of the ACE and ACTN3 genes predict rates of sprint and run events and are characteristic of track and field events players and help detect sprinters' talents taking part in track and field events. (20)

All this proves that genes and genetic factors are very important in the selection process aiming at reaching top levels in sport. The use of genetic techniques in selecting and developing talents is receiving more and more consideration in the sport field. Review of research work and references on the topic revealed the ACE and ACTN3 genes as the most influential in physical and sport performance.

Phase I of the Sport Human Genome Project (SHGP) (selecting junior players in some track and field event) was implemented, with the aim of identifying the best human elements among juniors by conducting morphological, physical and physiological measurements on 2127 juniors. Out of those, the best 25 juniors were selected (27) and received a general physical training in order to develop and improve their general physical fitness, in preparation for Phase II. Subject of the present study (genetic tests).

The selection process, according to authors of this paper, must be based on a scientific system including morphological, physical, physiological and genetic measurements (Phase II), leading to identification of the relationship between hereditary genes and their morphological and physiological significance when selecting juniors in the track and field events. This will be done by studying the genotypes of the ACE II, DD and the ACTN3
RR, XX genes. The Sport Human Genome Project (SHGP) is a real revolution in modern technology and needs the financial support of the public sports organizations. Such support will determine results of competitions in the future and help effect the expected results in sport performance.

\section{Objectives}

The study aims at implementing the preliminary phase of junior athlete selection for the Sport Human Genome Project in some track and field events (phase II) through:

1. identifying genotypes of the angiotensinconverting enzyme gene ACE (DD, II) and the ACTN3 (RR , XX) gene in the research sample in the Sport Human Genome Project (SHGP)in some track and field events (phase II)

2. identifying the best human elements in the sample according to the ACE and ACTN3 gene tests

\section{Hypotheses}

1. Variance exists between the genotypes of the angiotensin-converting enzyme gene ACE (DD, II) and the ACTN3 (RR, XX) gene in the research sample in the Sport Human Genome Project in some track and field events (phase II).

2. Identifying the best human elements in the sample according to the ACE and ACTN3 gene tests

\section{Research procedures}

\section{Methodology: the descriptive method}

\section{Research sample:}

Juniors selected in Phase I of the Sport Human Genome Project $(\mathrm{N}=20)$, in the age span $13-14$ years old $(13.80 \pm 0.410)$ as shown in Table 1 
Table (1)

Mean, standard deviation, skewness and kurtosis coefficients of the basic measurements describing research sample

\begin{tabular}{|c|l|c|c|c|c|c|}
\hline No & \multicolumn{1}{|c|}{ Variables } & Minimum & Maximum & Mean \pm SD & Skewness co-efficient & $\begin{array}{c}\text { Kurtosis } \\
\text { co-efficient }\end{array}$ \\
\hline 1 & Age (y) & 13 & 14 & $13.8 \pm 0.41$ & -1.624 & 0.699 \\
\hline 2 & Weight (kgm) & 39 & 65 & $49.6 \pm 6.53$ & 0.745 & 0.732 \\
\hline 3 & Total height $(\mathrm{cm})$ & 1.53 & 1.59 & $1.67 \pm 0.947$ & 1.196 & 3.196 \\
\hline
\end{tabular}

\section{The basic study}

On completion of the selection process of the research sample, the basic study was conducted by developing and improving the general physical fitness of sample subjects, and taking the study measurements in the period $15 / 10 / 2012-10 / 11 / 2012$ as follows:

1. conducting morphological, physical and physiological measurements in playgrounds of the Faculty of Physical Education for boys, Alexandria University in the period $15-$ 22/10/2012;

2. conducting the gene analysis using the Polymerase Chain Reaction (PCR) in the laboratory of the Genetics Department of the Medical Research Institute Alexandria University in the period $03-10 / 11 / 2012$.

\section{Study measurements}

The tests appropriate for the age span of the sample were conducted based on the study by Saad Elalem (2012)(26) as follows:

Morphological measurements: weight $(\mathrm{kgm})$, total height $(\mathrm{cm})$, body mass indicator $(\mathrm{kgm} / \mathrm{m} 2)$, muscle mass weight $(\mathrm{kgm})$, thoracic cage journey $(\mathrm{cm})=$ circumference of chest in maximum exhalation - circumference of chest in maximum inhalation. (10)
Physical measurements: high start $30 \mathrm{~m}$ sprint time (s), six seconds sprint distance (m), 50m sprint time $(\mathrm{s}), 300 \mathrm{~m}$ running test $(\mathrm{s}), 600 \mathrm{~m}$ running and walking test $(\mathrm{m})$, one mile running and walking test $(1609 \mathrm{~m})$,broad jump distance (cm), vertical jump distance (cm). (10), (17), (13)

Physiological measurements: pulse in rest (pulse/minute), blood pressure (systolic and diastolic) (mercury $\mathrm{mm}$ ), vital capacity $(\mathrm{mm})$, cardiac output, heart beat volume (litre), pulse rate $(\mathrm{m})$, VO2max $(\mathrm{ml} / \mathrm{kgm} / \mathrm{m})$. this was measured based on the following equation: $\mathrm{VO} 2 \mathrm{max}=108.844-[0.1636 \mathrm{x}$ weight $(\mathrm{kgm})]$ - [1.438 x 1 mile time (m)] - [0.1928 x pulse immediately after running]. (10), (16), (13)

Biological measurements: genotype analysis using the Polymerase Chain Reaction (PCR) as follows:

\section{DNA Isolation from Blood;}

2. ACE Gene, ACTN3 Gene PCR Reaction, using the primer of each gene (from Metabion, Germany) (Table 2), PCR Master Mix and FastDigest Dde I (from Fermentas, Lithuania). (3), (8), (14)

Table (2)

DNA Primers used for ACE and ACTN3 genes in PCR analysis

\begin{tabular}{|c|c|c|c|c|}
\hline \multicolumn{2}{|c|}{ Primer } & Sequence $\left(5^{\prime} \rightarrow 3^{\prime}\right)$ & $\begin{array}{c}\text { PCR } \\
\text { Product }\end{array}$ & CO \\
\hline \multirow{2}{*}{ ACE } & FP & 5'- CTG GAG ACC ACT CCC ATC CTT TCT-3' & $190 / 490 \mathrm{bp}$ & 69.4 \\
\cline { 2 - 6 } & RP & 5'- GAT GTG GCC ATC ACA TTC GTC AGA T-3' & $190 / 490 \mathrm{bp}$ & 71.8 \\
\hline ACTN3 & FP & 5'- CTG TTG CCT GTG GTA AGT GGG -3' & $191 \mathrm{bp}$ & 67.3 \\
\cline { 2 - 6 } Exon 16 & RP & 5'- TGG TCA CAG TAT GCA GGA GGG -3' & $191 \mathrm{bp}$ & 66.5 \\
\hline
\end{tabular}

$$
F P=\text { Forward Primer }
$$

1. identifying the genotypes of ACE Gene and ACTN3 Gene: the outcome of the ACE Gene and ACTN3 Gene PCR is carried to the

\section{$\boldsymbol{R P}=$ Reverse Primer}

Agarose Gel Electrophoresis and photographed by a camera within 15 minutes to obtain the size of the amplification alleles (Figures 1 and 2). 
On completion of data collecting, they were all statistically treated and analyzed.

Figure (1)

Size of the amplification alleles $D$ and I in the ACE Gene when the Dde I restriction enzyme digests nitrogen bases
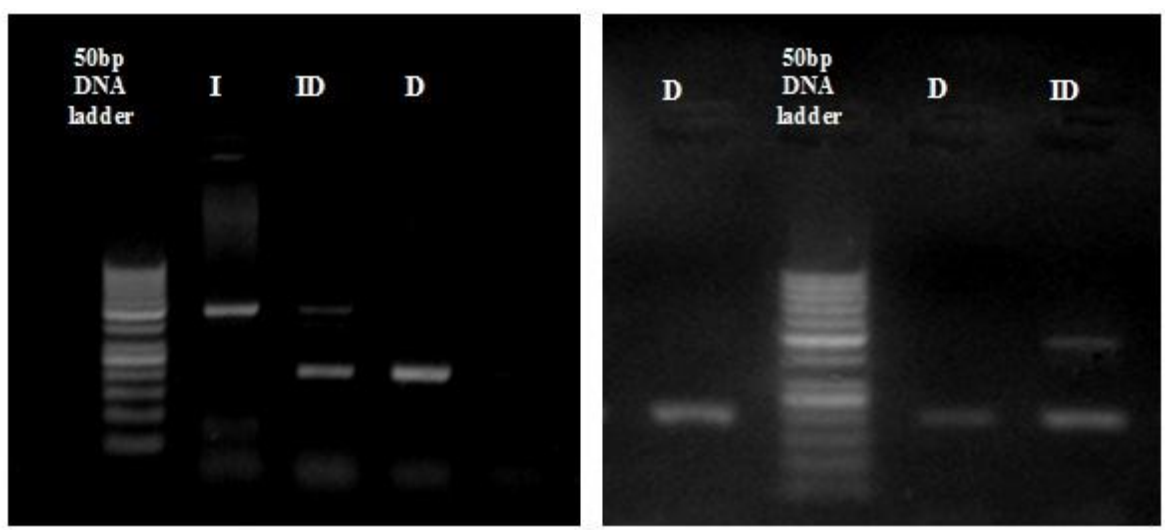

Figure (2)

Size of the amplification alleles $R$ and $X$ in the ACTN3 Gene when the Dde I restriction enzyme digests nitrogen bases

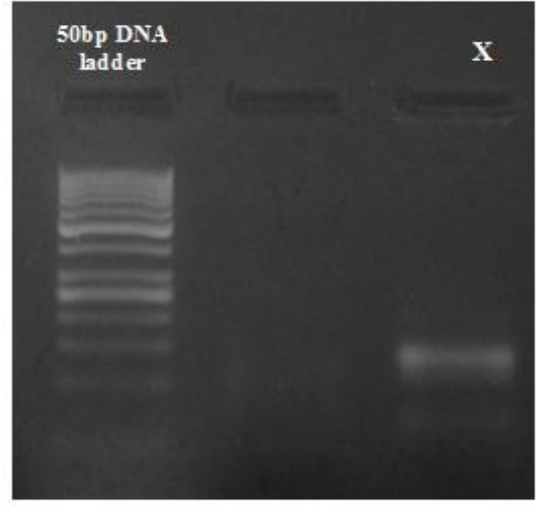

\section{Statistical treatment}

Data were statistically treated by using the computer software SPSS PASW Statistics 18 to Results

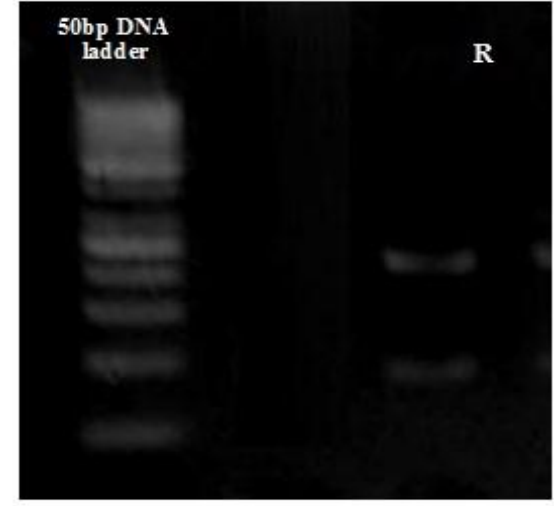

find Mean, Standard Deviation, Skewness, Kurtosis, Percentage, Kruskal-Wallis.

Table (3)

Frequency and percentage of the ACE genotypes

\begin{tabular}{|c|c|c|c|c|c|}
\hline \multirow{2}{*}{ Variables } & \multicolumn{3}{|c|}{ Genotype (N=20) } & \multicolumn{2}{c|}{ Allele } \\
\cline { 2 - 6 } & II & ID & DD & I & D \\
\hline Frequency & 2 & 14 & 4 & 18 & $55 \%$ \\
\hline Percentage & $10 \%$ & $70 \%$ & $20 \%$ & $45 \%$ & 22 \\
\hline
\end{tabular}


Figure (3)

Percentage of the distribution of the $A C E$ genotype in the research sample
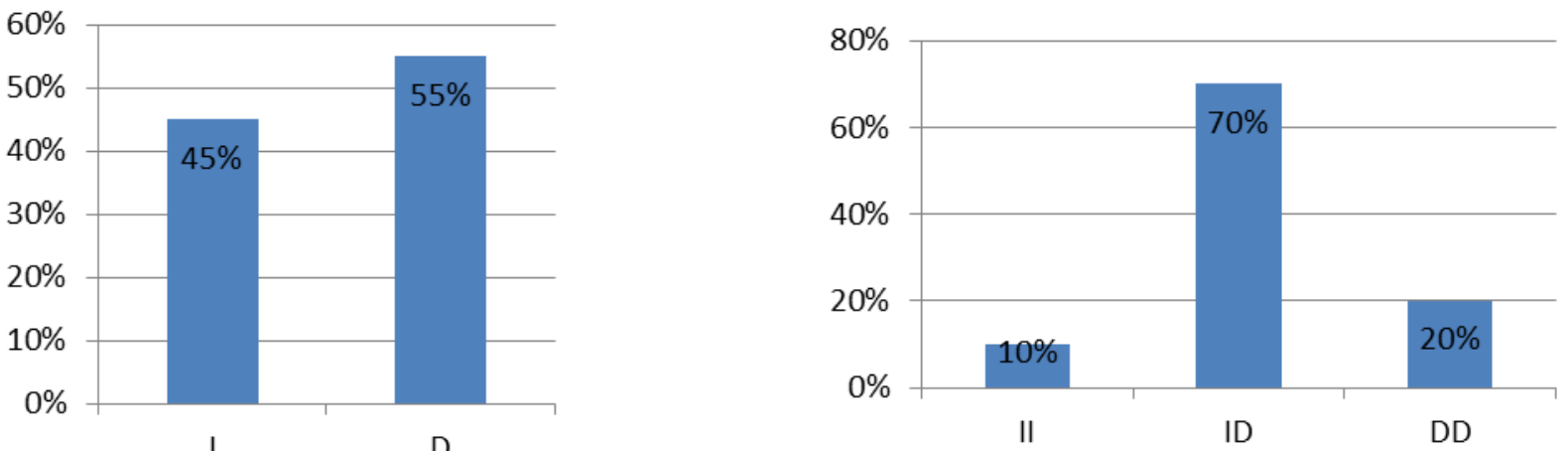

Table (4)

Value of Kruskal-Wallis test, mean and standard deviation of the morphological, physical and physiological measurements of the ACE genotypes

\begin{tabular}{|c|c|c|c|c|c|c|}
\hline \multirow{2}{*}{\multicolumn{2}{|c|}{ Measurements }} & $\begin{array}{c}\text { Genotype II } \\
\mathrm{N}=2\end{array}$ & $\begin{array}{c}\text { Genotype ID } \\
\mathrm{N}=14\end{array}$ & $\begin{array}{c}\text { Genotype DD } \\
\mathrm{N}=4\end{array}$ & \multirow{2}{*}{$\begin{array}{l}\mathrm{H} \\
\text { test }\end{array}$} & \multirow[t]{2}{*}{ Sig. } \\
\hline & & Mean \pm SD & Mean \pm SD & Mean \pm SD & & \\
\hline \multirow{5}{*}{ 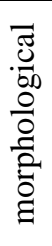 } & weight (kgm) & $47.5 \pm 3.54$ & $49.5 \pm 6.32$ & $51 \pm 9.35$ & 0.211 & 0.9 \\
\hline & total height $(\mathrm{cm})$ & $1.82 \pm 0.19$ & $1.65 \pm 0.06$ & $1.65 \pm 0.1$ & 1.766 & 0.414 \\
\hline & $\begin{array}{c}\text { body mass indicator } \\
(\mathrm{kgm} / \mathrm{m} 2)\end{array}$ & $17.12 \pm 0.84$ & $18.2 \pm 2.29$ & $18.73 \pm 1.81$ & 0.833 & 0.659 \\
\hline & muscle mass weight (kgm) & $22.72 \pm 2.52$ & $25.09 \pm 4.56$ & $26.29 \pm 5.13$ & 0.637 & 0.727 \\
\hline & thoracic cage journey $(\mathrm{cm})$ & $11 \pm 1.41$ & $10.07 \pm 1.49$ & $8.5 \pm 2.38$ & 3.018 & 0.221 \\
\hline \multirow{8}{*}{ 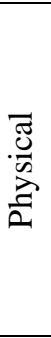 } & high start 30m sprint time (s) & $5.03 \pm 0.29$ & $5.23 \pm 0.35$ & $5.36 \pm 0.22$ & 2.303 & 0.316 \\
\hline & 50m sprint time $(\mathrm{s})$ & $7.63 \pm 0.37$ & $7.97 \pm 0.5$ & $8.31 \pm 0.38$ & 3.346 & 0.188 \\
\hline & six seconds sprint distance $(\mathrm{m})$, & $37.55 \pm 2.33$ & $36.05 \pm 2.96$ & $34.64 \pm 2.05$ & 2.174 & 0.337 \\
\hline & $300 \mathrm{~m}$ running test $(\mathrm{s})$ & $51.16 \pm 3.31$ & $52.26 \pm 5$ & $56.22 \pm 7.36$ & 1.601 & 0.449 \\
\hline & $600 \mathrm{~m}$ running $(\mathrm{m})$ & $1.84 \pm 0.35$ & $1.89 \pm 0.34$ & $2.07 \pm 0.36$ & 0.987 & 0.61 \\
\hline & one mile running and walking time & $6.74 \pm 0.48$ & $6.94 \pm 1.51$ & $7.74 \pm 2.26$ & 0.833 & 0.659 \\
\hline & broad jump distance $(\mathrm{cm})$ & $2.15 \pm 0.07$ & $2.11 \pm 0.16$ & $1.94 \pm 0.24$ & 2.245 & 0.325 \\
\hline & vertical jump distance $(\mathrm{cm})$ & $42.5 \pm 0.71$ & $42.21 \pm 6.84$ & $37 \pm 7.39$ & 2.208 & 0.332 \\
\hline \multirow{6}{*}{ 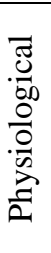 } & pulse in rest (pulse/minute) & $94.5 \pm 2.12$ & $85.64 \pm 9.39$ & $83 \pm 5.42$ & 4.132 & 0.127 \\
\hline & Systolic pressure (mercury $\mathrm{mm}$ ) & $117.5 \pm 4.95$ & $119.5 \pm 9.03$ & $124.25 \pm 7.8$ & 1.66 & 0.436 \\
\hline & diastolic pressure (mercury $\mathrm{mm}$ ) & $64.5 \pm 3.54$ & $69.29 \pm 9.6$ & $74 \pm 2.83$ & 2.096 & 0.351 \\
\hline & vital capacity $(\mathrm{mm})$ & $2.95 \pm 0.35$ & $2.62 \pm 0.36$ & $2.58 \pm 0.54$ & 1.298 & 0.523 \\
\hline & $\mathrm{VO} 2 \mathrm{max}(\mathrm{ml} / \mathrm{kgm} / \mathrm{m})$ & $62.85 \pm 8.61$ & $62.28 \pm 5.86$ & $66.62 \pm 3.71$ & 1.552 & 0.46 \\
\hline & cardiac output & $7.52 \pm 0.47$ & $6.43 \pm 0.92$ & $6.01 \pm 0.35$ & 5.287 & 0.071 \\
\hline
\end{tabular}

Table (5)

Frequency and percentage of the ACTN3 genotypes

\begin{tabular}{|c|c|c|c|c|c|}
\hline \multirow{2}{*}{ Variables } & \multicolumn{3}{|c|}{ Genotype (N=20) } & \multicolumn{2}{c|}{ Allele } \\
\cline { 2 - 6 } & $\mathrm{RR}$ & $\mathrm{RX}$ & $\mathrm{XX}$ & $\mathrm{R}$ & 20 \\
\hline Frequency & 4 & 12 & 4 & 20 & $50 \%$ \\
\hline Percentage & $20 \%$ & $60 \%$ & $20 \%$ & $50 \%$ & 20 \\
\hline
\end{tabular}


Figure (4)

Percentage of the distribution of the ACTN3 genotype in the research sample
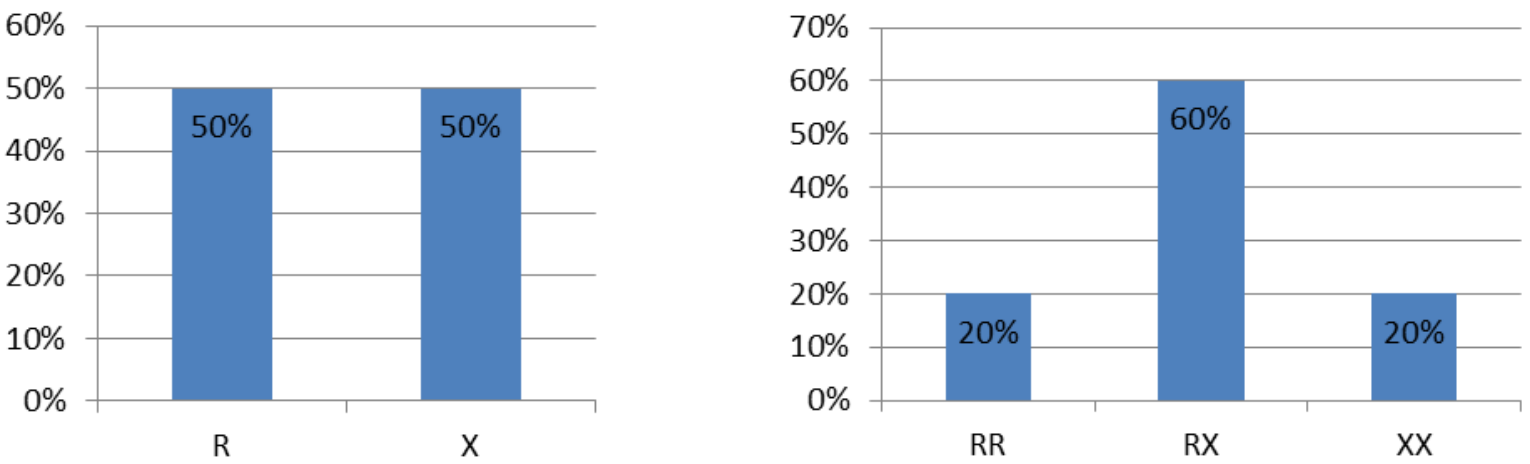

Table (6)

Value of Kruskal-Wallis test, mean and standard deviation of the morphological, physical and physiological measurements of the ACTN3 genotypes

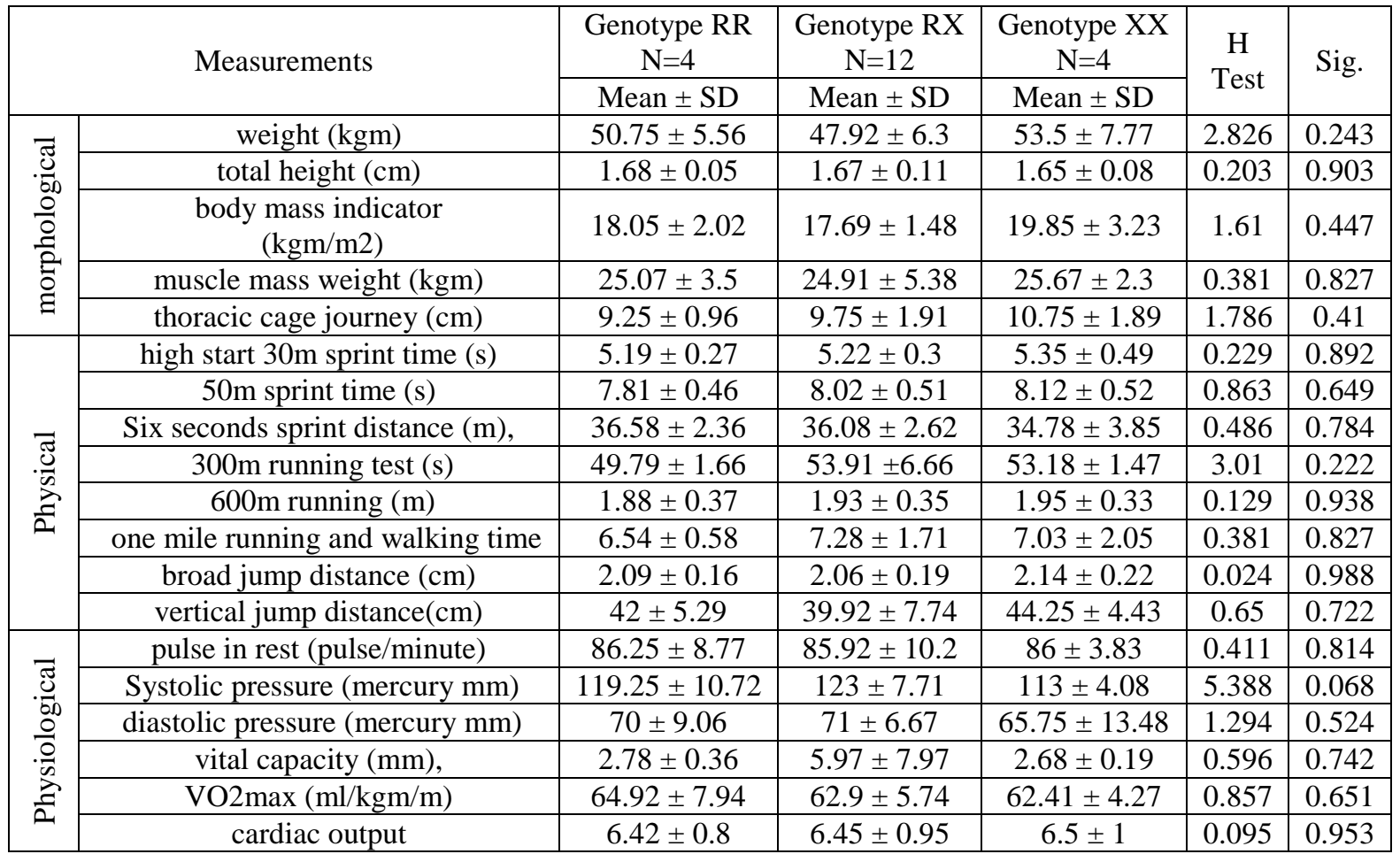

\section{Discussion of results}

Table 3 and Figure 3 show the percentages of the ACE genotypes as follows: the ID genotype occurred with the highest percentage $(70 \%)$, whereas the II genotype constituted the lowest percentage $(10 \%)$. The DD constituted $20 \%$, the $\mathrm{D}$ allele $55 \%$ and the I allele $45 \%$ of the research sample. This conforms with results reached by Ginevičienè V, et al (2009), emphasizing that genotypes of Lithuanian athletes' genotype II constituted the lowest percentage $(24.8 \%)$ while the genotype ID constituted the highest percentage $(47.2 \%)$. The genotype DD occurred with a percentage of 28\%. (10). The ACE gene has two forms of human performance- related alleles: alleleI, related to improving endurance, and allele $\mathrm{D}$, related to performance-driven ability. (23). Results of this research showed that the genotype II is less prevalent in research sample than the DD and DI genotypes of the ACE gene. Genetic selection is therefore necessary to detect those with this important genotype when selecting athletes for the track and field events, especially those requiring endurance.

According to Table 4, there are no statistically significant differences in the Kruskal-Wallis test $\mathrm{H}$ measurements between the ACE genotype, but variance exists in the mean favoring the II genotype in respect of morphological measurements (total height and thoracic cage 
journey) and all morphological and physiological measurements (systolic and diastolic pressure, vital capacity and cardiac output), favoring, however, the DD genotype in morphological measurements (weight, body mass indicator, muscular mass weight ) and physiological measurements (pulse in rest, VO2max) in research sample.

The non-existence of significant differences in measurements is due to the fact that sample subjects were chosen from the best juniors in Alexandria in Phase I of SHGP, and have already passed Phase I of selection which basically relied on morphological and physical measurements and which showed great similarity in the form and type of body and the physical level. Accordingly no significant differences occurred between sample subjects.

Athletes with genotype II were characterized by tall stature and low muscle mass which appeared in weight, muscle mass weight and body mass indicator. Several studies suggested that genotype II was related to endurance which in turn requires the lean type of body and a small muscle mass. Their thoracic journey in those same athletes was great, enabling them to deeply breathe, thus creating more endurance than in people with genotype DD.

Each sport has its own morphological and physiological characteristics which reflect physical requirements for motor performance in the training systems of each respective sport. (7). Charbonneau DE, et al (2008) also suggested that the muscle size, total mass and weight of persons with genotype DD are greater than those in persons with genotype II, in respect of trained or untrained leg muscle alike. They also suggested that the ACE genotype is related to basic differences in muscle size, but is not related to the response of muscle growth in strength training. (6)

Several studies showed that the D allele is basically related to an increase in the muscle strength and volume, an increase in the proportion of fast fiber muscles, and the athletes' ability and speed, while the genotype II has a great effect on physical performance of endurance athletes, because the allele $\mathrm{I}$ is the prevalent type of the ACE gene, and directly affects heart, blood circulation and blood pressure. This effect was therefore quite obvious in research sample. (1)

In the study on 215 marathon players, Woods D (2009) proved an increase in the genotype II in the best players. (32). Amr Rushdy (2007) also suggested a correlation between the genetic significance of the ACE gene and physical variables in long distances runners $(50 \mathrm{~m}$ sprint time, $800 \mathrm{~m}$ running time, $5000 \mathrm{~m}$ running time). (4)

According to Myerson S, et al (1999), there was an increase in the frequency of the allele I proportional with the increase in the running distance. In distances less than $200 \mathrm{~m}$, the figure was 20 , and in distances from $400 \mathrm{~m}$ to $3000 \mathrm{~m}$, it was 37 , whereas the figure in distances greater than $5000 \mathrm{~m}$ was 34 , respectively. Theses results emphasize the existence of a positive relationship between the allele $\mathrm{I}$ in the ACE gene and the ability to perform distinguished endurance. (18)

Persons with genotype II of the ACE gene also possess physiological abilities suitable for endurance-based events, due to lower blood pressure and increase in vital capacity and cardiac output, which are all important indicators in endurance athletes. This can be attributed to the effect of the ACE gene on physiological systems, and lays more emphasis on the importance of selecting track and field players on a genetic basis.

The study by Amr Mohamed Rushdy (2007) suggests a correlation between the genetic significance of the ACE gene and some physiological variables (systolic and diastolic pressure) in long distances runners (4), and Neeser K. J. (2009) mentions that genes have a great effect on VO2max, maximum heart beats, maximum pulmonary ventilation. There is evidence that cardiac output is affected by genes (19)

Williams A, et al (2004) indicated a correlation between the ACE II and endurance activity (aerobic) in elite athletes. (31)

Results also conform with the findings of the studies by Al-Shaimaa Gaber Al-Deeb (2008) and Saad Elalem (2012) who found that people with the geno variety of the ACE DD are more capable of performing short distances sprints, whereas those with the geno variety of the ACE 
II are more capable of performing long distances running. (3), (26)

This paper also found that people with the DD genotype did not have the ability for speed or strength. This conforms with results reached by Papadimitriou I. D. et al (2009), to the effect that there is weak evidence that the genotype ACE DD may affect performing sprints in Greek athletes. (24)

The above statements show that the ACE gene is an important gene that can be relied on when selecting talents in the track and field events, especially those requiring endurance. Persons with the genotype II had better morphological, physical and physiological measurements.

The genetic diversity of the ACE gene is closely related to morphological, physical and physiological indicators. Genotype II was found to be correlated to track and field events requiring speed and endurance. This proves the fact that the ACE gene is one of the most important genes that may help in selecting junior athletes, especially in the running events. The genotype II occurred in $10 \%$ of the sample subjects, indicating the need to find and develop those with this genotype so that they can be future champions.

Table 5 and Figure 4 show the percentages of the ACTN3 genotypes as follows: the RX genotype occurred with the highest percentage (60\%), whereas the RR genotype constituted the lowest percentage $(20 \%)$. The XX constituted $20 \%$, the $\mathrm{R}$ allele $50 \%$ and the $\mathrm{X}$ allele $50 \%$ of the research sample. This conforms with results reached by Saad Elalem (2012), emphasizing that genotype RX of the ACTN3 occurred with the highest percentage $(61.11 \%)$, whereas the RR genotype constituted the lowest percentage (29.63\%) in a sample of junior runners. (26)

According to Eynon N, et al (2009), the RR genotype constituted a percentage of $52 \%$ in runners. A remarkable variation was noted in the same genotype in endurance athletes, with a percentage of $18 \%$. The comparison between high level runners and national level runners showed higher occurrence of the allele $\mathrm{R}$ in high level runners, and a higher of significance of the genotype XX in endurance athletes (34\%) and sprinters $(13 \%)$. Allele $\mathrm{R}$ is therefore is related to performing high level sprinting, whereas allele $\mathrm{X}$ may not be decisive in endurance performance. (9)

The ACTN3 gene is a stimulant of the alpha actinin protein, which is the main component of the contraction system of skeletal muscles fast fibers, and which plays an important role in generating force in high speeds. Elite sprinters showed a high frequency of the RR genotype, compared to the XX genotype. (23)

According to Table 6, there are no statistically significant differences in the Kruskal-Wallis test $\mathrm{H}$ measurements between the ACTN3 genotype, but variance exists in the mean favoring the RR genotype in respect of morphological measurements (total height) and all physical measurements $(30 \mathrm{~m}$ and $50 \mathrm{~m}$ sprint time, $30 \mathrm{~s}$ sprint distance, $600 \mathrm{~m}$ time and 1 mile time) and physiological measurements (vital capacity, VO2max)), favoring, however, the XX genotype in morphological measurements (weight, body mass indicator, muscular mass weight and thoracic cage journey), physical measurements (broad jump and vertical jump) and physiological measurements (pulse in rest, systolic and diastolic pressure, and cardiac output) in research sample.

Results showed that persons with genotype RR had a tall stature, whereas persons with genotype $\mathrm{XX}$ had an increase in the muscle mass and body mass indicator as reflected in weight. Yang N, et al (2009) reached different results which showed that persons with genotype XX had a significant decrease in the muscle mass and fat mass, compared to persons with genotype RR. Body mass indicator in persons with genotype XX was much lower than in persons with genotype RR. The genetic diversity of the multi-form ACTN3 gene leads to the clearly defined apparent genotype (existence or non-existence of structural protein of the muscles) and biologically affects the performance of skeletal muscles in athletes. Absence of alpha-actinine-3 from fast muscle fibers adversely affects the activities of sprinting and strength. (33)

Genes play an important role in sport talents. They determine many aspects of talent, such as height, length of arms and legs and trunk. They also affect the size and composition of muscles (proportion of distribution of fast and slow fibers), and muscular strength. (19). There are 
numerous genetic factors that must be taken into consideration when selecting junior athletes. This can be done in junior centers in different sport federations, organizations and clubs. Such factors include height, weight because there is a relationship between the genetic increase of height and greater achievements mad by sprinters, runners and jumpers. (22)

Several studies prove that genotype RR is associated to strength and speed in athletes because it stimulates the growth of fast muscle fibers of the second type. According to Neeser, K. J. (2009), sprinters possess a high proportion of fast muscle fibers, responsible for fast contraction. It is the ACTN3 gene that produces the alpha actinine -3 protein in fast muscle fibers, associated in turn to better sprinting performance (19)

Results reached by also conform with results reached by Yang, N. et al (2009) in the study conducted on 525 Greek young people. Persons with genotype $\mathrm{XX}$ took a long time to complete the $40 \mathrm{~m}$ sprint. The average time was as follows: $\mathrm{XX}=6.13 \mathrm{~s} ; \mathrm{RX}=6.00 \mathrm{~s} ; \mathrm{RR}=5.92 \mathrm{~s}$ ). Sprint time for persons with genotype RR was better than that for persons with genotype RX, which, in turn, was better than that for persons with genotype XX. It is possible that alleles $\mathrm{R}$ and $\mathrm{X}$ have a common relative effect of alpha actinine- 3 in the fast muscle fibers. (33)

Results of the study conducted by Eynon, N, et al (2009) indicated that the genetic variety ACTN3 R577X in Israeli high level athletes shows that the allele $\mathrm{R}$ is associated to performing sprinting in high level athletes, while the allele $\mathrm{X}$ and genotype $\mathrm{XX}$ may not be decisive for endurance performance. (9)

Failure to reach excellence by persons with genotype RR in the research sample in ability measurements (broad jump and vertical jump) may be attributed to the fact that muscle strength appears later than speed in the age span of the research sample in which muscle strength has not grown. This in turn affects the low weight of muscle mass and body mass indicator in morphological measurements.

This may also be attributed to the fact that the effect of the genotype RR on performance does not appear except in maximum competition and beyond normal human activity (34). The current physical tests may not have stimulated fast muscle fibers of the second type which are stimulated by genotype RR, the basic component of alpha actinine- 3 protein in them. (26)

Mohamed Amin Ramadan (1995) suggested that the biological (physiological) characteristics distinguishing talented runners in the track and field events are vital capacity and VO2max (15)

Yang et al (2003) agree that athletes of speed and athletes of strength are similar in the forms of genotype ACTN3 with the low occurrence of the genotype XX and the high occurrence of the genotype RR. Contrarily, high level athletes of endurance show a higher occurrence of the genotype XX. Five studies followed which were conducted on high level athlete of speed and strength and which emphasized the basic fact that genotype $\mathrm{XX}$ is less frequent in athlete of speed and strength (34)

ACTN3 gene is thus concluded to be an important gene in events that depend on strength and speed because it builds up alpha actinine- 3 protein in fast muscle fibers of the second type, important for producing high speed and strength necessary for fast sprinting. This proves that the ACTN3 gene is important in selecting juniors for sprinting and speed events.

Saad Elalem (2012) stressed the need to develop a model for the selection of juniors in the community and schools. The model should start with an initial selection phase in which selection is made based on somatotype, and the physiological and physical status. In the second phase, selection is made by analyzing the hereditary genes of the ACE and ACTN3 genes. The third phase is one of specialized selection made according to requirements of the respective sport activity, focusing on genetic factors, environmental factors, nutrition and training. (26)

Importance of the ACE and ACTN3 genes in the process of selecting juniors for the track and field events is thus proved, and the study hypotheses are confirmed: Variance exists between the genotypes of the angiotensinconverting enzyme gene ACE (DD, II) and the ACTN3 (RR, XX) gene in the research sample in the initial phase of the Sport Human Genome Project in some track and field events (phase II). 
The best human elements in the sample were identified according to the ACE and ACTN3 gene tests. $10 \%$ of the juniors were found to be carrying the genotype ACE II and 20\% have the genotype ACTN3 RR. $30 \%$ of the sample subjects (20 juniors) were thus selected for Phase III of the Sport Human Genome Project in some track and field events, which is the specialization phase which aims at guiding juniors according to their physical and genetic abilities.

\section{Conclusions}

1. In the distribution of the genotypes of the ACE gene, the genotype ID occurred with the highest percentage (70\%), whereas the genotype II constituted $10 \%$ and the genotype DD $20 \%$. In the distribution of the genotypes of the ACTN3 gene, the genotype RX occurred with the highest percentage $(60 \%)$, whereas the genotype RX constituted $20 \%$ and the genotype XX $20 \%$ of the research sample.

2. There is a positive correlation between the genotypes of the ACE and ACTN3 genes when selecting juniors for the track and field events. Persons with the genotype ACE II have a higher ability for endurance activities, whereas persons with the genotype ACTN3 RR have a higher ability for speed and strength activities.

3. The best human elements in the sample were identified, represented by $30 \%$ of the research sample according to morphological, physical and physiological measurements, and the ACE and ACTN3 gene tests.

\section{Recommendations}

1. Phase III of selecting juniors for the Sport Human Genome Project (SHGP) in some track and field events should be implemented.

2. Phase I of the Sport Human Genome Project (SHGP) in some track and field events should be generalized in sports clubs to save time, money and effort.

3. The Sport Human Genome Project (SHGP) in some track and field events should be implemented by the Ministry of Sport on the national level of Egypt by people in charge of the project.

\section{References}

1. Ahmetov II, Rogozkin VA. (2009), Genes, Athlete Status and Training -An Overview, Genetics and Sports. Collins M. (ed), Medicine and Science in Sports and Exercise, Basel, Karger, vol 54, pp 43-71.

2. Al-Said Masoud Al-Qardawi (2007), Evaluating national projects to train juniors in track and field events in Egypt. Unpublished $\mathrm{Ph}$. D. dissertation, Faculty of Physical Education for Boys, Alexandria University, Alexandria.

3. Al-Shaimaa Gaber (2008), The ACE gene as a determinant in selecting runners and sprinters. Unpublished $\mathrm{Ph}$. D. dissertation, Faculty of Physical Education for Girls, Helwan University, Cairo.

4. Amr Mohamed Roshdy (2007), The relationship between molecular biology, some physiological variables and digital achievement level in track and field players. Unpublished Ph. D. dissertation, Faculty of Physical Education, Benha University.

5. Bahaa El-Din Salama (2008), Biochemical characteristics of sport physiology. First edition, Dar Al-Fikr Al-Araby, Cairo.

6. Charbonneau DE, Hanson ED, Ludlow AT, Delmonico MJ, Hurley BF, Roth SM. (2008), ACE genotype and the muscle hypertrophic and strength responses to strength training. Medicine and Science in Sports and Exercise, Apr;40(4):677-83.

7. Eisenmann JC, Malina RM. (2003), Age- and sex-associated variation in neuromuscular capacities of adolescent distance runners. Journal of Sports Sciences, Jul;21(7):551-557.

8. El Shafei SA, Zein El Din MH, Galal AF, Mokhtar MM. (2007), The association of Angiotensinogen Converting Enzyme (ACE) Insertion/ Deletion Polymorphism with Preeclamptic Women in Alexandria-Egypt. The Egyptian Journal of Medical Human Genetics, Vol.8, No.1.

9. Eynon N, Duarte JA, Oliveira J, Sagiv M, Yamin C, Meckel Y, Sagiv M, Goldhammer E. (2009), ACTN3 R577X Polymorphism and Israeli Top-level Athletes. International Journal Sports Medicine, Issue 09, 30: 695-698. 
10. Ginevičienė V, Kučinskas V, Kasnauskienė J. (2009), The angiotensin-converting enzyme gene insertion/deletion polymorphism in Lithuanian professional athletes. Acta Medica Martiniana, Vol.16, No. 1-2, pp 9-14.

11. Hadavi F, Tarbiat AZ. (2009), Talent Identification and Development Model in Iranian Athletics. IDOSI Publications, World Journal of Sport Sciences 2 (4): 248-253.

12. Hussein Ahmed Heshmat \& Abdel Kafi Abdel Aziz Ahmed (2010), A reference book for bio-technology and genetic doping drugs in sport. The Libyan Olympic Committee, Benghazy, Libya.

13. Mackenzie B. (2005), 101 Evaluation Performance Tests. Electric Word plc, London, 2005. pp 1-105.

14. Mayne IP, Kovach M. (2006), Examination of the ACE and ACTN3 genes in UTC varsity athletes and sedentary students. Southeastern Biology 53(2):267.

15. Mohamed Amin Ramadan (1995), Some biological characteristics of sport talents in track and field events. Journal of physical education and sport, No.22, Faculty of Physical Education for Boys, Helwan University.

16. Mohamed Nasr El-Din Radwan (1998), Methods of measuring physical effort in sport. First edition, Markaz Al-Kitab Publication House, Cairo.

17. Mohamed Sobhy Hassanein (2004), Measurement and evaluation in physical education and sport (Part 1), sixth edition, Dar Al-Fikr Al-Araby.

18. Myerson S, Hemingway $\mathrm{H}$, Budget $\mathrm{R}$, Martin J, Humphries S, Montgomery H. (1999), Human angiotensin I-converting enzyme gene and endurance performance. Journal of Applied Physiology, 87(4): 1313-1316.

19. Neeser KJ. (2009), The Genes who make the Champions: Can Genes predict Athletic Performance. Journal of Sports Science and Health Vol.10:106-132.

20. Onselen JV. (2008), The processes involved in track sprinting talent identification: a systematic review. an honors thesis, Faculty of Health Sciences, Nelson Mandela Metropolitan University.
21. Onywera VO. (2009), East African Runners: Their Genetics, Lifestyle and Athletic Prowess, Genetics and Sports. Collins M. (ed), Medicine and Science in Sports and Exercise, Basel, Karger, vol 54, pp 102-109

22. Osama Reyad (2003), Sport medicine and track and field events. First edition, Dar Al-Fikr Al-Araby, Cairo.

23. Ostrander EA, Huson HJ, Ostrander GK. (2009) Genetics of Athletic Performance. The Annual Review of Genomics and Human Genetics, 10:407-429.

24. Papadimitriou ID, Papadopoulos

C, Kouvatsi A, Triantaphyllidis C. (2009), The ACE I/D polymorphism in elite Greek track and field athletes. Journal of Sports Medicine and Physical Fitness, Dec;49(4):459-463.

25. Peltola E, Hill MR, Price AC, Simpson B. (2008), Talent identification at Qatar's ASPIRE Academy. New Studies in Athletics by IAAF, 23:3, 49-52.

26. Saad Fathallah Elalem (2012), The relationship between genotype and some physical and physiological evidence as indicator for selecting junior runners. Unpublished Ph. D. dissertation, Faculty of Physical Education for Boys, Alexandria University, Alexandria.

27. Samy Ibrahim Nasr \& Medhat Abdel Hamid Salem (2008), The preliminary phase of selecting juniors for the Sport Human Genome Project (SHGP) in some track and field events (Phase I). Journal of physical education and sport, Faculty of Physical Education for Girls, Alexandria University, Alexandria.

28. Schiffer J. (2008), Children and youths in athletics. New Studies in Athletics by IAAF, 23:3, 7-20.

29. Thompson WR, Binder-Macleod SA. (2006), Association of genetic factors with selected measures of physical performance. Physical Therapy. Vo 86, No 4, April;585-591.

30. Trent RJ, Yu B. (2009), The Future of Genetic Research in Exercise Science and Sports Medicine, Genetics and Sports. Collins M. (ed), Medicine and Science in Sports and Exercise, Basel, Karger, vol 54, pp 187-195.

31. Williams AG, Dhamrait SS, Wootton PT, Day SH, Hawe E, Payne JR, Myerson SG, 
World M, Budgett R, Humphries SE, 33. Yang N, Garton F, North K. (2009), aMontgomery HE. (2004), Bradykinin receptor Actinin-3 and Performance, Genetics and gene variant and human physical performance. Sports. Collins M. (ed), Med Sport Sci. Basel, Journal of Applied Physiology 96: 938-942.

Karger, vol 54, pp 88-101.

32. Woods D. (2009), Angiotensin-Converting Enzyme, Renin-Angiotensin System and Human Performance, Genetics and Sports. Collins M. (ed), Medicine and Science in Sports and Exercise, Basel, Karger, vol 54, pp 72-87.

34. Yang N, MacArthur DG, Gulbin JP, Hahn AG, Beggs AH, Easteal S, North K. (2003), ACTN3 Genotype Is Associated with Human Elite Athletic Performance. The American Journal of Human Genetics. 73:627-631. 